\title{
ASSESSMENT OF THE WEED INCIDENCE AND WEED SEED BANK OF CROPS UNDER DIFFERENT PEDOLOGICAL TRAITS
}

\author{
SKUODIENĖ, R. ${ }^{*}$ - REPŠIENĖ, R. - KARČAUSKIENĖ, D. - ŠIAUDINIS, G. \\ Vëžaičiai Branch of the Lithuanian Research Centre for Agriculture and Forestry \\ Gargždu 29, 96216 Vëžaičiai, Klaipéda distr., Lithuania \\ *Corresponding author \\ e-mail: regina.skuodiene@vezaiciai.lzi.lt; phone: +370-46-458-233 \\ (Received $27^{\text {th }}$ Sep 2017; accepted $15^{\text {th }}$ Jan 2018)
}

\begin{abstract}
Weed community variations result from an interaction of different cropping and pedo-climatic aspects. The aim of the study was to investigate changes of the weed incidence in limed and unlimed soils of different texture in the Western Lithuania. Soil acidity decrease from $\mathrm{pH}$ 4.2-5.8 to 5.1-6.4 resulted in total weed number decrease: in sandy soils it decreased by $46.7 \%$, in sandy loam soils - by $34.3 \%$ and in loam soils - by $24.0 \%$. However, due to better nutrient and growth conditions, the weed mass was 11.1$72.6 \%$ greater in limed soil. The annual weeds were spread much more in a sandy soil (94.1\% of the total weed number), while the perennial weeds - in a loam soil (51.2\%). In sandy soils of all surveyed sites, most weeds were monocotyledonous (on the average 64.8\%), while in sandy loam and loam soils dicotyledonous (70.6\%). The number of observed weed species was greater in sandy loam and loam soils both in crops and in the soil seed bank. Weed species diversity of the soil seed bank was particularly influenced by crop type and the crop preceding in the rotation. The most frequent weed species sequences in crops and soil seed bank matched by $67 \%$.

Keywords: agrobiological composition of weeds, most frequent weed species, soil contamination with weed seeds, soil texture, soil $\mathrm{pH}$
\end{abstract}

\section{Introduction}

Agricultural plants' productivity depends on geographical situation, soil, level of agriculture and agroclimatic conditions (Čiuberkis and Vilkonis, 2013). Weed growth is determined by many factors in addition to the soil's physical and chemical properties. These include field cropping history, proximity of sources of infestation, the weed seed population present or supplied to a field, water supply, and growing season conditions. The effects of soil structure, water-holding capacity, and nutrient level are more important than soil type (Zimdahl, 2007). Soil and crop management practices can directly influence the environment of seeds in the soil weed seed bank and can thus be used to manage seed longevity and germination behaviour of weed seeds (Hossain and Begum, 2015).

According to Radosevich et al. (2007), many weed species have patchy distributions in arable fields that can be strongly affected by their environments, in particular the soil. Weed community is changing depending on edaphic and climatic conditions (Walter et al., 2002) as well as the application of crop management measures (Kutyna and Mlynkowiak, 2014). For example, reduced soil tillage, and in some cases spring ploughing gave significantly higher aggregate stability than autumn ploughing, thus providing protection against erosion. However, decreasing tillage intensity increased the amounts of weeds, particularly of Poа апnиа on silt soil (Seehusen et al., 2017). It was established in other surveys, that soil management practices, such as soil tillage and crop rotation explain the majority of weed community variation across different soil typologies (Fried et al., 2008). Vidotto et al. (2016) indicates, that soil texture has 
significant influence on weed specific composition. Monocotyledonous weeds are spreading more rapidly in alkaline sandy soil (with high $\mathrm{pH}$ ) while dicotyledonous - in alkaline loam soil. Other researches suggests, that significant interactions occurred between weed species and soil texture, weed species and planting depth and soil texture and planting depth. For all weed species and soil textures, emergence decreased as planting depth increased with the greatest percent emergence at the soil surface (Hoyle et al., 2013).

Physical properties of the soil have a strong effect on buried-seed ecology and consequently on seed bank dynamics in the agroecosystem. Germination inhibition due to burial depth was found to be directly proportional to clay content and inversely proportional to sand content (Benvenuti, 2003).

Weediness evaluation in Lithuania was started in 1957. Herbicides were not widely used at that time. In winter crops there had been 348-609 unit $\mathrm{m}^{-2}$ of weeds and in spring crops - 291-591 unit $\mathrm{m}^{-2}$ of weeds. Perennial weeds were especially spread. After about 25 years, the weediness decreased by $60-80 \%$. The annual dicotyledonous weeds became dominant. At present time, however, a problem of the annual monocotyledonous weeds becomes apparent (Auškalnienė et al., 2011). Recently, more and more farmers move to extensive farming using small amounts of herbicides or no herbicides at all.

Bathygleyic Distric Glossic Retisol (RT) (WRB, 2014) prevailing in the West Lithuania are acid, low in organic matter and contain high level of toxic Al (Repsiene and Karcauskiene, 2016). According to these observations, we hypothesised that choosing different soil management practice (crop rotation, soil tillage, fertilisation) it is possible to affect not only chemical but also physical characteristics of the soil both in positive and negative ways. Given that management practices, the soil texture and $\mathrm{pH}$ status of soils can have a major impact on the weed flora, we utilised data from a field experiment to test the effects of soil acidity factors on the weed properties.

The aim of the study was to investigate changes of the weed incidence in limed and unlimed soils of different texture in the Western Lithuania.

\section{Materials and methods}

\section{Experimental site}

Experiments were carried out during the period 2012-2015 in different sites of the Western Lithuania, varying in their relief and soil characteristics.

The first experimental site was a coastal area of the Seaside Lowland in the Nemunas delta (Fig. 1). The geographical location of the site is Latitude $55^{\circ} 19 \mathrm{~N}$ and Longitude $21^{\circ} 35$ E. The soil was Bathihypogleyi-Dystri-Haplic Arenosols (ARh-dygld-w) (WRB, 2014) with a texture of sand.

The second experimental site was the Western Plateau of Žemaičiai Highland (Fig. 1). The geographical location of the site is Latitude $55^{\circ} 37 \mathrm{~N}$ and Longitude $21^{\circ} 57$ E. The soil was Bathygleyic Distric Glossic Retisol (RT) (WRB, 2014) with a texture of sandy loam.

The third experimental site was the Western Plateau of Žemaičiai Highland (Fig. 1). The geographical location of the site is Latitude $55^{\circ} 32 \mathrm{~N}$ and Longitude $21^{\circ} 54$ E. The soil was Hapli-Endohypogleyic Luvisol (LVg-n-w-ha) (WRB, 2014) with a texture of loam. 


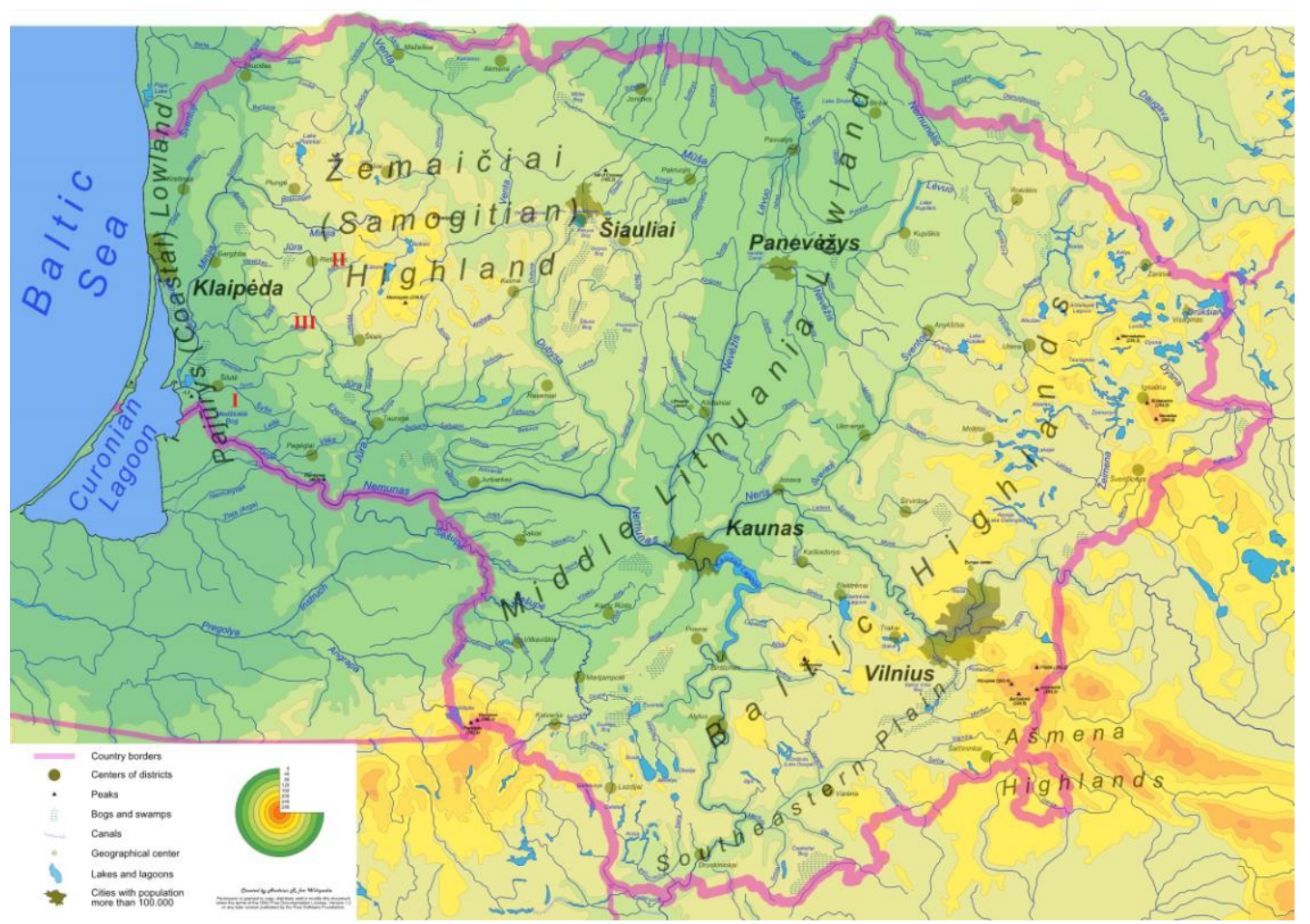

Figure 1. The locations of research area: I-first experimental site, II - second experimental site, III - third experimental site

These fields were chosen because they had a known history of weed infestation due to extensive farming mode. Soil properties were also considered in the study for each site; in particular, soil reaction $(\mathrm{pH})$ and texture (relative proportions of sand, silt and clay) (Table 1).

\section{Experimental design}

Field experiments in all surveyed sites were conducted according to the same scheme: 1) unlimed soil; 2) limed soil.

The experiment was established in four replications. The treatments were assigned randomly. The trial field area was $5.0 \mathrm{~m} \times 9.5 \mathrm{~m}=47.5 \mathrm{~m}^{2}$.

Liming was conducted with liming material - ground chalk containing $97.8 \%$ of $\mathrm{CaCO}_{3}$. The soil was limed once in 2011 before the trial arrangement. Liming material was scattered and incorporated with a cultivator at a depth of $0-15 \mathrm{~cm}$.

Sandy soil was limed with $4.5 \mathrm{t} \mathrm{ha}^{-1}$ of $\mathrm{CaCO}_{3}$, sandy loam soil - with $7.0 \mathrm{t} \mathrm{ha}^{-1}$ of $\mathrm{CaCO}_{3}$ and loam soil - with $6.0 \mathrm{tha}^{-1}$ of $\mathrm{CaCO}_{3}$. The quantities of liming material were calculated according to approved recommendations, soil type and texture and $\mathrm{pH}$ value.

Plant growing technology (soil tillage, fertilisation, plant care) was used in different experimental sites. Crop rotation (cereal and row crops) of the first surveyed site was as follows: winter triticale, potatoes, winter wheat, peas. Crop rotation (cereal and row crops) of the second surveyed site was as follows: spring rape, maize, maize, barley + undersowing (perennial grasses). Crop rotation (cereal crops) of the third surveyed site was as follows: spring wheat, winter rye, spring wheat, winter wheat. 
Table 1. Sites characteristics, Western Lithuania

\begin{tabular}{|c|c|c|c|}
\hline \multirow{2}{*}{ Indices } & \multicolumn{3}{|c|}{ Experimental site } \\
\hline & I & II & III \\
\hline \multicolumn{4}{|c|}{ Pedological indices } \\
\hline Soil type & Arenosols & Retisol & Luvisol \\
\hline Soil texture & Sand & Sandy loam & Loam \\
\hline Sand, $\%$ & $93.8 \pm 7.55$ & $65.1 \pm 5.20$ & $50.4 \pm 4.35$ \\
\hline Silt, \% & $3.6 \pm 0.25$ & $24.7 \pm 1.95$ & $30.7 \pm 2.45$ \\
\hline Clay, \% & $2.6 \pm 0.20$ & $10.2 \pm 0.80$ & $18.9 \pm 1.15$ \\
\hline $\mathrm{pH}_{\mathrm{KCl}}$ (unlimed soil) & $4.91 \pm 0.13$ & $4.20 \pm 0.26$ & $5.79 \pm 0.22$ \\
\hline $\mathrm{pH}_{\mathrm{KCl}}($ limed soil $)$ & $5.93 \pm 0.35$ & $5.08 \pm 0.17$ & $6.45 \pm 0.17$ \\
\hline Mobile $\mathrm{Al} \mathrm{mg} \mathrm{kg}{ }^{-1}$ (in unlimed soil) & $3.88 \pm 2.22$ & $31.64 \pm 13.12$ & 0.00 \\
\hline Mobile $\mathrm{P}_{2} \mathrm{O}_{5} \mathrm{mg} \mathrm{kg}^{-1}$ & $114.5 \pm 6.36$ & $225.0 \pm 38.59$ & $60.0 \pm 45.25$ \\
\hline Mobile $\mathrm{K}_{2} \mathrm{O} \mathrm{mg} \mathrm{kg}^{-1}$ & $74.0 \pm 19.8$ & $115.5 \pm 16.26$ & $81.5 \pm 17.68$ \\
\hline Humus, $\%$ & $1.66 \pm 0.16$ & $2.51 \pm 0.16$ & $2.95 \pm 0.18$ \\
\hline \multicolumn{4}{|c|}{ Climatic indices (SRC) } \\
\hline Total annual precipitation, $\mathrm{mm}$ & 801 & 816 & 816 \\
\hline Annual mean temperature, ${ }^{\circ} \mathrm{C}$ & 7.4 & 6.3 & 6.3 \\
\hline Growing season's total precipitation, $\mathrm{mm}$ & 508 & 495 & 495 \\
\hline Growing season's mean air temperature, ${ }^{\circ} \mathrm{C}$ & 12.9 & 11.9 & 11.9 \\
\hline
\end{tabular}

Note: SRC - The standard rate of climate

\section{Methods of analysis}

Agrochemical characteristics of the soil were determined from the soil samples taken from $0-20 \mathrm{~cm}$ layer before establishing the experiment: soil $\mathrm{pH}_{\mathrm{KCl}}$ was measured according to potenciometric method determined in $1 \mathrm{M} \mathrm{KCl}$ (soil - solution ratio 1:2.5 (ISO 10390:2005), available $\mathrm{P}_{2} \mathrm{O}_{5}$ and $\mathrm{K}_{2} \mathrm{O}$ - using Egner-Riehm-Domingo (A-L) method (LVP D-07:2012). Mobile Al was determined according ISO11260 and ISO14254 Sokolov method. Humus was determined according Tiurin method (ISO 10694:1995). Soil texture was determined according to the composition of three fractions: sand, silt and clay. Analysis was accomplished using Kaczynski method and modified according to FAO (ISO 11277:2009).

Weed record was performed in stationary areas $0.25 \mathrm{~m}^{-2}$ in size in six positions of every plot during crop maturity phase. The weeds were eradicated and their specific composition and dry matter mass were determined. Weed number was recalculated to weeds per $\mathrm{m}^{-2}$ and mass $-\mathrm{g} \mathrm{m}^{-2}$.

Soil contamination with weed seeds was investigated in the depths of $0-10 \mathrm{~cm}$ and 10-20 cm. Soil samples were collected using an agrochemical drill during crop maturity phase. The soil was dried out. One hundred gram (100 g) dry soil sample was weighed and wet-sieved through a $0.25 \mathrm{~mm}$ sieve until all contents of the soil were washed out. Remained mineral part of the soil was separated from the organic part and weed seeds using the saturated salt solution. Weed seed number $(A)$ was recalculated to thousands of unit $\mathrm{m}^{-2}$ using the following Equation 1:

$$
A=n \cdot h \cdot p \cdot 100
$$


where,

$A=$ weed seed number (unit $\mathrm{m}^{2}$ ),

$n=$ seed number in a sample (unit),

$h=$ depth of the soil $(\mathrm{cm})$,

$p=$ soil density $\left(\mathrm{g} \mathrm{cm}^{-3}\right)$.

\section{Agrometeorological conditions}

Meteorological conditions in 2012-2015 were diverse. Climatic conditions of the first experimental site were evaluated according to the data of Silute meteorological station (Fig. 2). During the vegetation period in 2012 and later in the year, the amount of precipitation was greater by 12.2 and $12.7 \%$ compared to the long-term mean (Table 1). During the vegetation period in 2013, 2014, 2015 and later in the year, the amount of precipitation was smaller compared to the long-term mean by, respectively: $16.5 ; 40.2$; 40.0 and 15.0; 32.8; 15.7\%. The month of July in 2014 and the months of August and October in 2015 were especially dry.

The average air temperature during the vegetation period in 2013 and 2014 was greater than the long-term mean by, respectively, 0.7 and $1.1^{\circ} \mathrm{C}$, and the average temperature of the year in 2013, 2014 and 2015 were greater by, respectively, $0.5 ; 1.2$ and $1.3^{\circ} \mathrm{C}$.

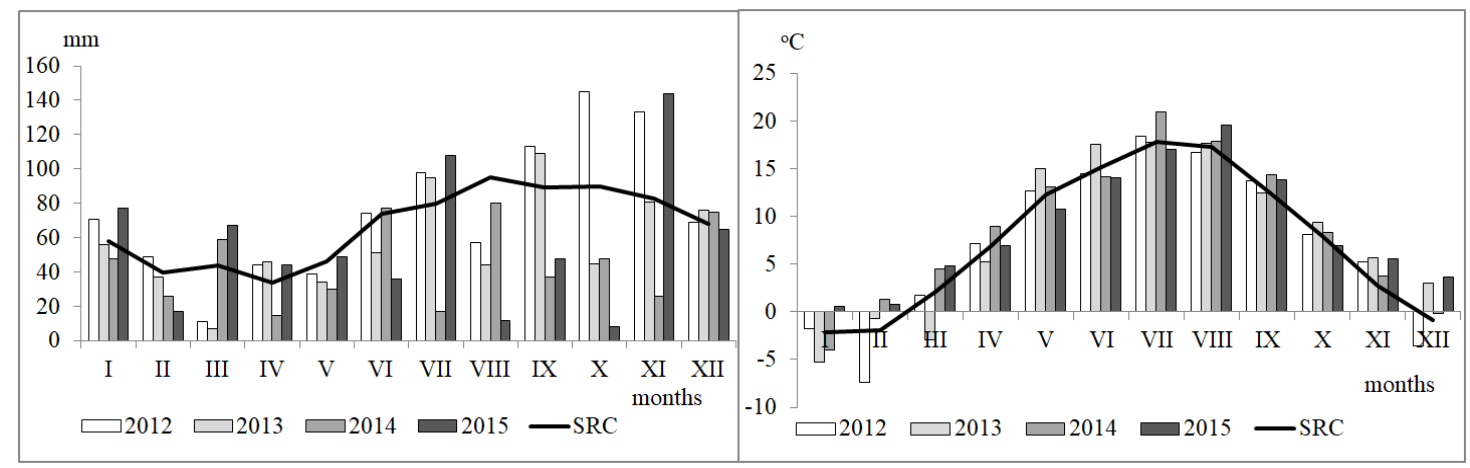

Figure 2. The average daily air temperature $\left({ }^{\circ} \mathrm{C}\right)$ and precipitation $(\mathrm{mm})$ during the study period (2012-2015). Data from the Šilute (first experimental site) Meteorological Station. Note: $S R C$ - The standard rate of climate

Climatic conditions of the second and third experimental sites were evaluated according to the data of Laukuva meteorological station (Fig. 3). The weather in 2012 was more humid: the amount of precipitation during the vegetation period was greater by $10.9 \%$ and later in the year it was greater by $4.5 \%$ compared to the long-term mean. The amount of precipitation in 2013, 2014 and 2015 during the vegetation period and later in the year was smaller compared to the long-term mean by, respectively, 5.1; $10.9 ; 29.1$ and $11.4 ; 15.3 ; 8.2 \%$. The months of August and October in 2015 were especially dry.

The average air temperature during the vegetation period was greater than the longterm mean in 2012, 2013 and 2014 by, respectively, $1.2 ; 0.7$ and $1.1^{\circ} \mathrm{C}$, and the average temperature of the year was greater in 2013, 2014 and 2015 by, respectively, 1.0, 1.2 and $1.3^{\circ} \mathrm{C}$. 


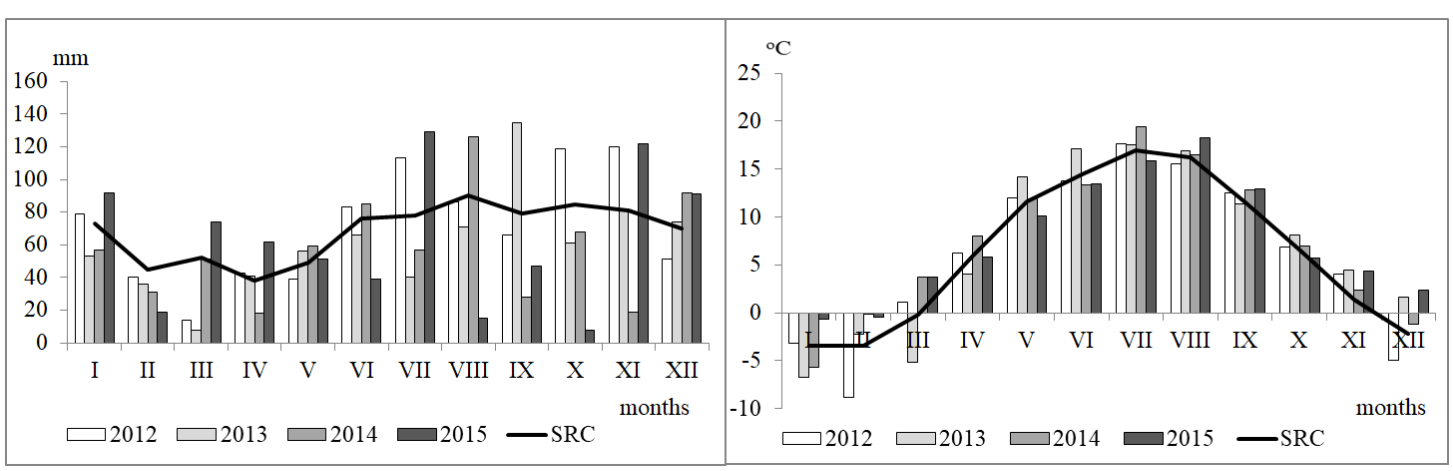

Figure 3. The average daily air temperature $\left({ }^{\circ} \mathrm{C}\right)$ and precipitation $(\mathrm{mm})$ during the study period (2012-2015). Data from the Laukuva (second and third experimental sites) Meteorological Station. Note: SRC - The standard rate of climate

\section{Statistical analysis}

Significance of the differences between the means was determined according to the Fisher's protected least significant difference (LSD) at 0.05 probability level. The data were processed using software ANOVA (Clewer and Scarisbrick, 2001). Data of weed density and mass were transformed according to the recommended procedures, using Equation 2:

$$
Y=\sqrt{x+1}
$$

where $x$ is the primary data, $Y$ is transformed data of weed density and mass, however, means on the original scales are reported (Onofri et al., 2010).

Correlation-regression analysis was also performed. The symbols used in the paper are: *significant at $\mathrm{P}<0.05$, and **significant at $\mathrm{P}<0.01$, ns - not significant.

\section{Results and discussion}

\section{Weed community diversity}

Anthropogenic activity has the impact on biodiversity changes. Weed community diversity is affected by crop rotation, fertilization, technologies application (especially the use of herbicides) (Andreasen and Streibig, 2011). Crop weed infestations mainly depend on weed species which dominate the weed flora at different soil acidity and nutrient content in soil (Skuodienè and Repšienè, 2009; Karcaukiene et al., 2016).

Crop weediness and soil contamination with weed seeds depended on applied crop management measures and crop condition. In experimental areas, different in edaphic (environmental) conditions, 41 weed species were found. Independently from different soil $\mathrm{pH}$, the number of weed species in sandy loam and loam soils was greater by 1.5 and 3.0 times compared to a sandy soil. (Table 2). All weed species (in surveyed sites) were determined to belong to 16 families from Magnoliophyta division and one family from Equisetophyta division. Number of observed weed species was great in loam soils. A number of factors may contribute to this effect: extensive farming mode, even in wheat mono-cropping. 
Independently from different soil texture, a positive liming effect on crop weediness was estimated in all surveyed sites. The greater competitive ability of crops of the rotation resulted in general decrease of crop weediness. The number of weeds per square metre and their dry matter mass in many ways were significantly lower compared to unlimed plots (Table 2). In unlimed sandy soil, on the average, 65.3 units of weeds per square metre were estimated, in sandy loam soil - 14.0 units and in loam soil - 166.3 units of weeds. In limed sandy soil the weed number was lower by $46.7 \%$, in sandy loam soil - by $34.3 \%$ and in loam soil it was lower by $24.0 \%$ compared to unlimed plots.

Due to better nutrition and growth conditions in limed soil, a tendency of weed mass increase was observed. In a sandy soil the weed mass was greater by $65.3 \%$, in a sandy loam soil - by $72.6 \%$ and in a loam soil it was greater by $11.1 \%$ compared to unlimed plots. Under the similar environmental conditions in a sandy loam soil with $\mathrm{pH} 5.2$, the weed number was 86.9 units per square metre and their mass $-54.7 \mathrm{~g}$. (Skuodiene et al., 2016).

A similar tendency was established estimating a mass of the single weed. Literature indicates, that dry matter mass of the single weed depended on favourable nutrition and meteorological conditions, fertilisation and cultured plants' competition as well as the competitive ability that were formed by preceding crops (Arlauskienè and Maikštenienè, 2005). A mass of the single weed depended on soil edaphic conditions and weediness intensity. Together with decrease of weed number $\left(r=-0.405^{*}\right)$ and increase of their mass $\left(r=0.432^{*}\right)$, the mass of a single weed was increasing. The greatest mass was in crops in a sandy loam soil, respectively: $3.9 \mathrm{~g}$ in unlimed soil and $10.4 \mathrm{~g}$ in limed soil. Due to continuous cropping for several years, the lowest (1.0-1.6 g) mass of a single weed was estimated in crops of high weediness. In general, the average mass of a single weed was determined by a total number of weeds, development stage of individual weed species and weed mass.

Table 2. Agrobiological composition of weeds

\begin{tabular}{c|c|c|c|c|c|c}
\hline \multirow{2}{*}{ Weeds indices } & \multicolumn{6}{|c}{ Experimental site } \\
\cline { 2 - 8 } & \multicolumn{2}{|c|}{ I (Sand) } & \multicolumn{2}{c}{ II (Sandy loam) } & \multicolumn{2}{c}{ III (Loam) } \\
\cline { 2 - 8 } & $\begin{array}{c}\text { Unlimed } \\
\text { soil }\end{array}$ & $\begin{array}{c}\text { Limed } \\
\text { soil }\end{array}$ & $\begin{array}{c}\text { Unlimed } \\
\text { soil }\end{array}$ & Limed soil & $\begin{array}{c}\text { Unlimed } \\
\text { soil }\end{array}$ & $\begin{array}{c}\text { Limed } \\
\text { soil }\end{array}$ \\
\hline Number of weed species & 9 & 7 & 12 & 12 & 23 & 25 \\
Weed number, plants m $^{-2}$ & 65.3 & $34.8^{*}$ & 14.0 & $9.2^{*}$ & 166.3 & 126.4 \\
Weed DM mass, g m ${ }^{-2}$ & 49.0 & $81.0^{*}$ & 55.4 & $95.6^{*}$ & 69.2 & 76.9 \\
Mass of a single weed, g & 1.04 & $2.81^{*}$ & 3.96 & $10.39^{* *}$ & 1.00 & 1.63 \\
Annual dicotyledonous, \% & 22.4 & 36.2 & 37.1 & 73.8 & 43.5 & 58.8 \\
Annual monocotyledonous, \% & 69.0 & 60.6 & 10.0 & 0.0 & 0.0 & 0.2 \\
Perennial dicotyledonous, \% & 8.2 & 3.2 & 9.3 & 9.8 & 26.9 & 23.2 \\
Perennial monocotyledonous, \% & 0.0 & 0.0 & 33.6 & 8.2 & 28.5 & 16.8 \\
\hline
\end{tabular}

* and ** - the least significant at $P<0.05$ and $P<0.01$, respectively

The annual weeds spread in cereal and row crops rotation, respectively: in a sandy soil $-94.1 \%$, in a sandy loam soil $-60.4 \%$ of the total weed number. Perennial weeds, 
in the rotation with nearly the same crop species grown for every year, had formed $51.2 \%$ of the total weed amount.

In sandy soils the most weeds of all investigated crops were monocotyledonous (on the average $64.8 \%$ ) and in sandy loam and loam soils - dicotyledonous (70.6\%).

Crop weediness depended on edaphic conditions of the area. It is stated, that linear correlation analysis identified some significant relationships between the pedological parameters $\mathrm{pH}$, sand, silt and clay and some weed indices (Vidotto et al., 2016). Correlation analysis showed that soil texture had significant impact on weed number and agrobiological distribution and soil $\mathrm{pH}$ was significant for a mass of the single weed (Table 3).

Table 3. Linear correlation coefficients ( $r$ ) of the relationships among some pedological parameters and weed indices

\begin{tabular}{c|c|c|c|c}
\hline Characters & pH & Sand & Silt & Clay \\
\hline Weed number, plants $\mathrm{m}^{-2}$ & $\mathrm{~ns}$ & $-0.396^{*}$ & $0.401 *$ & $0.387^{*}$ \\
Mass of a single weed, g & $-0.455^{*}$ & $\mathrm{~ns}$ & $\mathrm{~ns}$ & $\mathrm{~ns}$ \\
Annual dicotyledonous, \% & $0.385^{*}$ & $0.532^{* *}$ & $0.579 * *$ & $0.499 * *$ \\
Annual monocotyledonous, \% & $-0.380^{*}$ & $-0.901 * *$ & $-0.853^{* *}$ & $-0.899 * *$ \\
Perennial dicotyledonous, \% & $0.474 * *$ & $-0.676^{* *}$ & $0.630^{* *}$ & $0.691 * *$ \\
Perennial monocotyledonous, \% & $\mathrm{ns}$ & $-0.725^{* *}$ & $0.701 * *$ & $0.698^{* *}$ \\
\hline
\end{tabular}

$*$ and $* *$ - the least significant at $P<0.05$ and $P<0.01$, respectively; ns - not significant

\section{Weed seed bank}

The seed bank is an indicator of past and present weed populations. It is also the main source of arable weed propagules and can have severe and long-lasting effects on crop yields (Sosnoskie et al., 2006). There are enormous numbers of viable weed seeds in the soil. According to the average data, there are 17.0 to 38.8 thousands of weed seeds per square metre in the soil seed bank (Table 4). During the research, 35 weed species were found in the soil seed bank. The number of weed species in sandy loam and loam soils was greater by 1.4 times compared to a sandy soil.

The total amount of weed seeds in limed sandy loam soil was significantly lower compared to unlimed soil of the same texture. In limed sandy soil the number of weeds was lower by $15.5 \%$ and in a sandy loam soil it was lower by $39.5 \%$ compared to unlimed plots. There were no significant differences in a loam soil. It is likely that no significant differences were obtained because cereals had been continuously cropped for several years. Soil contamination with weed seeds depends on crop condition and the application of crop management measures and corresponds to patterns that the amount of weed seeds in the soil depends on plants that were grown before and agrotechnique that was used (especially the use of herbicides) (Menalled et al., 2001; Sadrabadi Haghighi et al., 2013; Woźniak and Soroka, 2015).

Seeds are dispersed both horizontally and vertically in the soil profile. Benvenuti (2007) indicates that the vertical position of the seed was dependent on soil texture. Data of our research showed that weed seed number in the upper $(0-10 \mathrm{~cm})$ and the deeper $(10-20 \mathrm{~cm})$ layers of the soil differed (Table 4). The soil texture had the impact on weed seed distribution in different soil layers. In light-textured soil (I experiment) in the depth of 0-10 cm, the number of weed seeds was lower than in the depth of 10-20 
$\mathrm{cm}(47.7 \%$ of the total weed amount). In a sandy loam soil of the II experiment in 0 $10 \mathrm{~cm}$ layer there were $51 \%$ of weed seeds while in a loam soil $-59.2 \%$. Gselman and Kramberger (2004) and Janicka (2006) indicate that the greatest seed reserves were in the surface layer of the soil $(0-5 \mathrm{~cm})$.

Table 4. Weed seed bank in the topsoil

\begin{tabular}{c|c|c|c|c|c|c}
\hline \multirow{2}{*}{ Seed bank indices } & \multicolumn{4}{|c}{ Experimental site } \\
\cline { 2 - 7 } & \multicolumn{2}{|c|}{ I (Sand) } & \multicolumn{2}{c}{ II (Sandy loam) } & \multicolumn{2}{c}{ III (Loam) } \\
\cline { 2 - 7 } & $\begin{array}{c}\text { Unlimed } \\
\text { soil }\end{array}$ & Limed soil & $\begin{array}{c}\text { Unlimed } \\
\text { soil }\end{array}$ & Limed soil & $\begin{array}{c}\text { Unlimed } \\
\text { soil }\end{array}$ & $\begin{array}{c}\text { Limed } \\
\text { soil }\end{array}$ \\
\hline Number of weed species & 13 & 10 & 19 & 15 & 20 & 13 \\
Seeds, unit $\mathrm{m}^{-2} 0-20 \mathrm{~cm}$ & 38837 & 32808 & 28177 & $17046^{*}$ & 26532 & 28109 \\
Seeds, unit $\mathrm{m}^{-2} 0-10 \mathrm{~cm}$ & 18515 & 15677 & 15270 & $8165^{*}$ & 14731 & 17685 \\
Seeds, unit $\mathrm{m}^{-2} 10-20 \mathrm{~cm}$ & 20322 & 17131 & 12907 & 9241 & 11801 & 10425 \\
\hline
\end{tabular}

* and ** - the least significant at $P<0.05$ and $P<0.01$, respectively

Although, during the investigation, 41 weed species were found in crops and 35 species in the seed bank, only a few of species were spread. In crops, 11 species were present on more than $20 \%, 5$ species - on more than $50 \%$ and 2 species - on more than $70 \%$ of the surveyed sites (Table 5). In the soil seed bank, 12 species were present on more than 20\%, 6 species - on more than $50 \%$ and 4 species on more than $70 \%$ of the surveyed sites.

Independently from the soil texture, all surveyed sites were mostly contaminated with seeds of Chenopodium album L., Fallopia convolvulus L., Persicaria lapathifolia L. Weed species diversity of the soil seed bank was particularly influenced by crop type and the crop preceding in the rotation. The most frequent weed species sequences in crops and soil seed bank matched by $67 \%$. According to other surveys conducted in sandy loam soils, the weed species in crops and soil seed bank matched by $27-40 \%$ (Skuodienè et al., 2013).

The most frequent weed species in crops and soil seed bank were as follows:

Sandy soil (I experiment). Echinochloa crus-galli (L.) P.Beauv., Fallopia convolvulus L., Sonchus arvensis L., Spergula arvensis L., Persicaria lapathifolia L. the light-demanding but shade-tolerant weeds dominated. Spergula arvensis L., Fallopia convolvulus L. and Echinochloa crus-galli (L.) P.Beauv. formed the greatest part of the soil seed bank.

Sandy loam soil (II experiment). Elytrigia repens L., Persicaria lapathifolia L., Fallopia convolvulus L., Chenopodium album L., Polygonum aviculare L. - the weeds preferring fertile soils dominated. Chenopodium album L., Fallopia convolvulus L. and Persicaria lapathifolia $\mathrm{L}$. formed the greatest part of the soil seed bank.

Loam soil (III experiment). Galeopsis tetrahit L., Tripleurospermum perforatum (Merat.) M.Lainz, Persicaria lapathifolia L., Sonchus arvensis L., Elytrigia repens L. the hardy-annual, over-wintering and perennial weeds dominated. Fallopia convolvulus L., Tripleurospermum perforatum (Merat.) M.Lainz, Chenopodium album L., Persicaria lapathifolia L. and Viola arvensis Murray formed the greatest part of the soil seed bank. 
Table 5. Frequency of encounters for the most diffused weed species across all surveyed sites

\begin{tabular}{|c|c|c|c|}
\hline \multicolumn{2}{|l|}{ Aboveground } & \multicolumn{2}{|l|}{ Seed bank } \\
\hline Species & $\begin{array}{c}\text { Encounter } \\
\text { frequency } \\
(\%)\end{array}$ & Species & $\begin{array}{c}\text { Encounter } \\
\text { frequency } \\
(\%)\end{array}$ \\
\hline Persicaria lapathifolia $\mathrm{L}$. & 100 & Chenopodium album $\mathrm{L}$. & 96 \\
\hline Fallopia convolvulus $\mathrm{L}$. & 80 & Fallopia convolvulus $\mathrm{L}$ & 96 \\
\hline Sonchus arvensis L. & 70 & Persicaria lapathifolia $\mathrm{L}$ & 92 \\
\hline Viola arvensis Murray. & 70 & Viola arvensis Murray. & 75 \\
\hline Elytrigia repens L. & 60 & Echinochloa crus-galli (L.) & \\
\hline Polygonum aviculare $\mathrm{L}$. & 50 & P.Beauv. & 54 \\
\hline Spergula arvensis $\mathrm{L}$. & 50 & Spergula arvensis $\mathrm{L}$. & 54 \\
\hline Echinochloa crus-galli (L.) & 40 & Scleranthus annuus L. & 42 \\
\hline P.Beauv. & 40 & Galeopsis tetrahit $\mathrm{L}$. & 42 \\
\hline Galeopsis tetrahit $\mathrm{L}$. & 40 & Rumex acetosella $\mathrm{L}$. & 38 \\
\hline Gnaphalium uliginosum L. & 40 & Stellaria media (L.) Vill. & 33 \\
\hline Equisetum arvense $\mathrm{L}$. & 40 & Tripleurospermum perforatum & \\
\hline Chenopodium album $\mathrm{L}$. & 20 & (Merat.) M.Lainz & 29 \\
\hline & & Sonchus arvensis L. & 25 \\
\hline
\end{tabular}

\section{Conclusions}

Weed community variation and soil contamination with weed seeds resulted from different soil $\mathrm{pH}$, pedological aspects and cropping management. Together with decreasing soil acidity from $\mathrm{pH} 4.2-5.8$ to $\mathrm{pH}$ 5.1-6.4, the total number of weeds decreased by $24.0-46.7 \%$. However, due to better nutrient and growth conditions, the weed mass was $11.1-72.6 \%$ greater in limed soil.

The mass of a single weed was determined by a total number of weeds, development stage of individual weed species and weed mass. The mass of a single weed increased, together with a decrease of weed number $\left(r=-0.405^{*}\right)$ and increase of their mass $\left(r=0.432^{*}\right)$. The greatest mass of a single weed was in crops of the least weediness, respectively: $3.9 \mathrm{~g}$ in unlimed soil and $10.4 \mathrm{~g}$ in limed soil. The least mass (1.0-1.6 g) of a single weed was determined in crops where the weed number was the greatest.

The annual weeds were spread much more in a sandy soil $(94.1 \%$ of the total weed number), while the perennial weeds - in a loam soil (51.2\%).

In sandy soils of all surveyed sites, most weeds were monocotyledonous (on the average $64.8 \%$ ), while in sandy loam and loam soils - dicotyledonous (70.6\%).

There were 17.0 to 38.8 thousands of weed seeds per square metre in the soil seed bank. The smallest amount of weed seeds was found in a sandy loam soil, while in a sandy soil it was the greatest. The soil texture had the impact on weed seed distribution in different soil layers. In sandy soil in the depth of $0-10 \mathrm{~cm}$, the number of weed seeds was $47.7 \%$ of the total weed amount, in a sandy loam soil $-51 \%$, in a loam soil $-59.2 \%$.

The number of observed weed species was greater in sandy loam and loam soils both in crops and in the soil seed bank. The most frequent weed species sequences in crops and soil seed bank matched by $67 \%$. Soil was mostly contaminated with seeds of Chenopodium album L., Fallopia convolvulus L. and Persicaria lapathifolia L. 
Effective control of the weediness is possible only when the optimal $\mathrm{pH}$ reaction of the soil is maintained and the proper crop rotation is applied. Under the changing climatic conditions weediness management is going to be even more difficult, therefore the scientific researches will have to be oriented to ecophysiological investigations of weeds.

Acknowledgments. The paper presents research findings, obtained through the long-term research programme "Productivity and sustainability of agricultural and forest soils" implemented by Lithuanian Research Centre for Agriculture and Forestry.

\section{REFERENCES}

[1] Arlauskienè, A., Maikštėnienè, S. (2005): The effect of legume preceding crop biomass on weed infestation in cereals. - Vagos 66(19): 7-16.

[2] Auškalnienè, O., Pšibišauskienė, G., Auškalnis, A., Lazauskas, S., Povilaitis, V., Sakalauskienè, S., Sakalauskaite, J., Duchovskis, P., Raudonius, S. (2011): Changes of segetal flora in Lithuania over the last decades. - Trends of Rural Development in the Knowledge Society 2: 217-222.

[3] Benvenuti, S. (2003): Soil texture involvement in germination and emergence of buried weed weeds. - Agronomy Journal 95: 191-198.

[4] Benvenuti, S. (2007): Natural weed seed burial: effect of soil texture, rain and seed characteristics. - Seed Science Research 17(3): 211-219.

[5] Čiuberkis, S., Vilkonis, K. K. (2013): Weeds in agro-ecosystems of Lithuania. - AB Spauda, Vilnius (in Lithuanian).

[6] Clewer, A. G., Scarisbrick, D. H. (2001): Practical statistics and experimental design for plant and crop science. - Wiley and Sons, Chichester.

[7] Fried, G., Norton, L. R., Reboud, X. (2008): Environmental and management factors determining weed species composition and diversity in France. - Agriculture, Ecosystems and Environment 128: 68-76.

[8] Gselman, A., Kramberger, B. (2004): Longevity and vertical distribution of dandelion (Taraxacum officinale F. Weber.) seeds in meadow soil. - Grassland Science in Europe 9: 252-254.

[9] Hossain, M. M., Begum, M. (2015): Soil weed seed bank: Importance and management for sustainable crop production - A Review. - Journal of the Bangladesh Agricultural University 13(2): 221-228.

[10] Hoyle, J. A., McElroy, J. S., Guertal, E. A. (2013): Soil texture and planting depth affect large crabgrass (Digitaria sanguinalis), Virginia buttonweed (Diodia virginiana), and cock's-comb kyllinga (Kyllinga squamulata) emergence. - HortScience 48(5): 633-636.

[11] Janicka, M., (2006): Species composition of the soil seed bank in comparison with the floristic composition of meadow sward. - Grassland Science in Europe 11: 200-202.

[12] Karcauskiene, D., Ciuberkis, S., Raudonius, S. (2016): Changes of weed infestation under long-term effect of different soil $\mathrm{pH}$ levels and amount of phosphorus:potassium. - Acta Agriculturae Scandinavica, Section B - Soil \& Plant Science 66(8): 688-697.

[13] Kutyna, I., Młynkowiak, E. (2014): The influence of differented natural and agrotechnical ecological conditions on the number of species in segetal communities and their mean number in the phytosociological releve. - Folia Pomeranae Universitatis Technologie Stetinensis Agric., Aliment., Pisc., Zootech. 312(31): 69-96.

[14] Menalled, F. D., Gross, K. L., Hammond, M. (2001): Weed aboveground and seedbank community responses to agricultural management systems. - Ecological Applications 11(6): 1586-1601.

[15] Onofri, A, Carbonell, E. A., Piepho, H. P., Mortimer, A. M., Cousens, R. D. (2010): Current statistical issues in weed research. - Weed Research 50: 5-24. 
[16] Radosevich, S. R., Holt, J. S., Ghersa, C. M. (2007): Ecology of Weeds and Invasive Plants: Relationship to Agriculture and Natural Resource Management (3ed.). - John Wiley and Sons, New York.

[17] Repsiene, R., Karcauskiene, D. (2016): Changes in the chemical properties of acid soil and aggregate stability in the whole profile under longterm management history. - Acta Agriculturae Scandinavica, Section B - Soil \& Plant Science 66(8): 671-676.

[18] Sadrabadi Haghighi, R., Critchley, N., Leifert, C., Eyre, M., Cooper, J. (2013): Individual and interactive effects of crop type and management on weed and seed bank composition in an organic rotation. - International Journal of Plant Production 7(2): 243-268.

[19] Seehusen, T., Hofgaard, S., Tørresen, K. S., Riley, H. (2017): Residue cover, soil structure, weed infestation and spring cereal yields as affected by tillage and straw management on three soils in Norway. - Acta Agriculturae Scandinavica, Section B Soil and Plant Science 67(2): 93-109.

[20] Skuodienè, R., Repšienè, R. (2009): The effects of organic fertilisers and liming on segetal flora in a sustainable crop rotation on acid soil. - Zemdirbyste-Agriculture 96(4): 154-169.

[21] Skuodienè, R., Karčauskienė, D., Čiuberkis, S., Repšienė, R., Ambrazaitienè, D. (2013): The influence of primary soil tillage on soil weed seedbank and weed incidence in cerealgrass crop rotation. - Zemdirbyste-Agriculture 100(1): 25-32.

[22] Skuodienè, R., Karčauskienè, D., Repšienè, R. (2016): The influence of primary soil tillage, deep loosening and organic fertilizers on weed incidence in crops. - ZemdirbysteAgriculture 103(2): 135-142.

[23] Sosnoskie, L. M., Herms, C. P., Cardina, J. (2006): Weed seed bank community composition in a 35-yr-old tillage and rotation experiment. - Weed Science 54: 263-273.

[24] Vidotto, F., Fogliatto, S., Milan, M., Ferrero, A. (2016): Weed communities in Italian maize fields as affected by pedo-climatic traits and sowing time. - European Journal Agronomy 74: 38-46.

[25] Walter, A. M., Christensen, S., Simmelsgaard, S. F. (2002): Spatial correlation between weed species densities and soil properties. - Weed Research 42: 26-38.

[26] Woźniak, A., Soroka, M. (2015): Biodiversity of weeds in pea cultivated in various tillage system. - Romanian Agricultural Research 32: 231-237.

[27] WRB. (2014): World reference base for soil resources 2014. International soil classification system for naming soils and creating legends for soil maps. - World Soil Resources Reports No. 106. FAO, Rome.

[28] Zimdahl, R. L. (2007): Fundamentals of Weed Science. - Academic Press, San Diego, CA. 